\title{
Poetisk landskab
}

\author{
- et motiv i ny tysk litteratur
}

\author{
Steen KlitgÅrd Povlsen
}

I den tyske delstat Nordrhein-Westfalen, i området Ostwestfalen-Lippe, nærmere bestemt Kreis Höxter opstår i disse år en poesipark. Konceptet er beslægtet med de 'land art'-parker, der rundt om i verden har flyttet skulpturer ud af museerne og ud i landskabet og forbundet kunstoplevelse med vandring i naturen. Ideen til "Poetische Landschaft" i Ostwestfalen-Lippe er udviklet af Brigitte Labs-Ehlert fra Literaturbüro Detmold, og hun har sammen med forfatteren Peter Waterhouse ${ }^{I}$ og den schweiziske arkitekt Peter Zumthor samlet en række digtere fra otte forskellige lande, herunder Inger Christensen fra Danmark, forfattere der skriver tekster, der skal placeres i og på huse, som Zumthor distribuerer strategisk i landskabet. Centralt i komplekset skal desuden opføres et bibliotek med foredragssal, hvor der også kan holdes koncerter. Her skal efterhånden samles et stort materiale om forholdet mellem litteratur, kunst og landskab, og her skal man kunne fordybe sig, før eller efter at man vandrer gennem poesien i naturen eller den poetiske natur.

"Poetische Landschaft" skulle oprindeligt have været skabt i forbindelse med 'Expo 2000'-udstillingen i det nærliggende Hannover, men blev ikke færdig til tiden og er i skrivende stund stadig under projektering. Men i januar 200I blev der afholdt en konference i Schwalenberg, hvor projektet blev præsenteret og diskuteret, og materialet fra denne 'Literaturbegegnung', der fandt sted under mottoet "Wer Eile hat, verliert seine Zeit", er fremlagt i den rigt udstyrede Raum für Sprache - Raum für Literatur: IX. Literaturbegegnung Schwalenberg 2001, udgivet af Brigitte Labs-Ehlert. ${ }^{2}$ Peter Zumthor forestiller sig i sit indlæg forskellige scenarier for kombinationen tekst-landskab, f.eks.:

Jeg forestiller mig, at en tekst bliver skrevet til et sted. I samme øjeblik, den er skrevet, flyver den væk fra sit oprindelsessted ud $i$ verden og treffer der mange andre steder. Dér taler den om sin oprindelse. Og om sin flugt. En kvinde finder den og bringer den tilbage til dens oprindelsessted. I den forbindelse må hun foretage en rejse, må tage af sted og se efter.Ankommet til stedet, læser hun teksten. Endnu engang. ${ }^{3}$

I dette landskab indsætter han huse, og hans bidrag munder ud i en vision om den store syntese:

Palimpsest - teksten overskriver huset overskriver stedet. Sprog forbundet med jorden. Jordberøring, ført frem til bestemte punkter. Energipunkter, ekstatiske punkter i landskabets krop, opsporet og bragt til form. 4

På samme måde taler Brigitte Labs-Ehlert i sit bidrag om sammensmeltningen mellem tanke og beskuelse, mellem erindring og nutid $i$ et næsten mystisk punkt: "Stedets utopiske kunst, hvor nutid kan opleves, hvor beskuelse og sansning kan føre til erkendelse".s

Sig nu ikke, at dette er et specielt tysk fænomen. Da Goethe lod sin helt Werther søge ud i naturen med sin poesibog, efterlignede hele Europa ham ganske vist; men det viste jo netop, at denne forbinden litteratur med landskab ikke blot var et tysk behov. Og ganske vist har tysk litteratur og kunst dyrket hjemstavnen og det regionale med exceptionel lidenskab siden Goethe; men vi er vel for længst holdt op med at forveksle tyske excesser som f.eks. den nazistiske dyrkelse af 'Blut und Boden’ med tysk

Passage $43-2002$ 
kultur som sådan. Hvor den nazistiske regionalisme var lukket $i$ aggressivt had til det fremmede, er gruppen omkring "Poetische Landschaft" international og åben over for landskabets mangfoldighed. Herom minder ikke mindst japaneren Yoko Tawadas bidrag.

Men det er notorisk, at den lokale identitetsopfattelse er veludviklet i det moderne Tyskland. Prøv bare at søge på områder og småbyers hjemmesider og sammenlign dem med danske. F.eks. Höxters med den omtrent lige så store Silkeborgs. Tyskernes retorisk svulmende, historisk minutiøs og detaljeret, danskernes kort og informativ. Og det er selvfølgelig ikke fordi silkeborgenserne holder mindre af deres by end beboerne i Höxter, det er et spørgsmål om kulturel stil. "Det regionale, ja det provinsielle var længe et tysk varemærke”, skriver Per Øhrgaard i Gaeld og arv ${ }^{6}$ og gennemgår i et stort essay de sidste 200 års kamp i tysk bevidsthed mellem den regionale forankring og et overordnet nationalt kulturbegreb. Tyskland blev sent samlet til én nation, og historien har vist farerne ved denne samling, sådan som intellektuelle som f.eks. Grass og Enzensberger har påpeget. Günter Grass' skepsis mod et genforenet Tyskland efter Murens fald var bl.a. begrundet i denne modvilje mod et stort samlet Tyskland i Europas midte.

Måske er en sådan diffus modvilje mod det store Tyskland også en del af baggrunden for det indtryk, der møder én, når man læser sig igennem dele af den nye litteratur, der i disse år under stigende international bevågenhed bobler frem i vores sydlige naboland: landskabets store betydning. Som de følgende eksempler vil vise, ikke et idyllisk, uforstyrret landskab, langt fra, men et konkret, faktisk eksisterende landskab, et bestemt sted i verden, lige nu. Det er en god idé ved læsningen af ny tysk litteratur at være udstyret med et detaljeret Tysklandskort, som man ofte med fordel kan læse parallelt med teksten.7 Problemerne er af generel karakter, men de foregår et ganske bestemt sted. Det uendeligt store i det uendeligt små.

Tyskland, ja, men hvor ligger det? ${ }^{8}$ Det umiddelbare svar er, at det ligger i midten. Få måneder før han i 200 I blev dræbt i en trafikulykke på motorvejen nord for London udsendte W. G. Sebald, der foruden at være forfatter arbejdede som professor i ny tysk litteratur ved universitet i Norwich, romanen Austerlitz. Den handler om alle de rædsler, tyskerne har udvirket eller været involveret i i Europas nyere historie. Fortælleren, Austerlitz, er tjekkisk jøde og blev lige for den tyske besættelse af hans land, I938, sendt med en børnetransport til England, hvor han har levet siden. Romanen er centreret om hans søgen efter spor af faderen og moderen, den sidste omkom i Theresienstadt, og besøget dér er kulminationen på Austerlitz' mange besøg på fæstninger og borge. Men overalt i landene rundt om Tyskland: Belgien, England, Frankrig, Schweiz og Tjekkiet finder Austerlitz spor af tyskernes hærgen.

Det er en stor, forunderlig og dybt bevægende roman, og alle dens forviklede tråde kan ikke udredes her. Henimod slutningen foretager Austerlitz imidlertid for første gang en rejse ind i selve Tyskland, ind i mørkets hjerte - en gentagelse af hans rejse fra Prag til Hoek van Holland kort før krigen. Og hvad oplever han her: et nydeligt, velplejet og fredeligt landskab, et ideal som han genkender som det billede, der hele hans liv har ligget under hans drøm om et utopia. Og da han til sidst når Rhinen, hans hjerteflod, bliver landskabet "forhistorisk" og "mytologisk". ${ }^{9}$ Han oplever det som at genfinde en tvillingebror, eller som om han har fundet et sted uden for tid, hvor gamle legender alligevel hele tiden kan fortælles, et sted malet af berømte kunstnere og alligevel et "Intetsted", et "utilgængeligt rige". Men også med mindelser om Styx, dødens flod; og i den efterfølgende rejseaktivitet, der i romanens rum ender uafsluttet, uden konklusion, føres Austerlitz mere og mere ind på kirkegårde: til gravpladsen ved Tower Hamlet i London, til Père Lachaise i Paris, etc. Også Theresienstadts bibliotek er på en måde en mægtig kirkegård, et minde om den død der altid har været slæbet fra de tyske hæres hærgen i Europa Midt i dette kaos ligger det tyske landskab da som et ikon af den store, utopiske fred, et "Kein Ort. Nirgends". ${ }^{\text {io }}$

Også en anden vigtig roman i ny tysk litteratur beskriver en rejse gennem Tyskland, her fra nord til syd, men også her med dødens ikon for enden af 
rejsen. Christian Krachts debutroman Faserland blev ved sin fremkomst I995 udråbt til den første tyske pop-roman: et dokument om en rusmiddelforbrugende, medie- og modevant tysk ungdom, skrevet i dens egen jargon. Det er den, men den er meget mere; den er også en gennemskrivning af Tyskland som mytologisk landskab, $i$ en dobbeltbevægelse ud af det og ind i det.

Landskab i traditionel forstand er der nu ikke meget af i denne roman, hvor jeg-fortælleren bevæger sig fra Sylt i nord til Zürich i syd, og hovedsageligt fortæller om drukfester $\mathrm{i}$ de store byer Hamburg, Frankfurt, Heidelberg og München. Men Tyskland og dets landskab er hele tiden til stede for hovedpersonen som en undergrund - ja, myte: "Sild er egentlig superdejlig. Himlen er vældig stor, og jeg har sådan en følelse af at kende øen grundigt. Jeg mener, jeg kender det der ligger under og bagved øen, jeg ved ikke, om jeg her har udtrykt mig rigtigt. Jeg kan selvfølgelig også tage fejl", ${ }^{\text {II }}$ hedder det i begyndelsen af rejsen. Senere føler han, at han skal til Frankfurt, "Sådan ind i Tysklands midte, som om jeg ikke kan gøre det anderledes" (p. 67). Som om en styrelse eller en underliggende kode bestemmer hans øjensynligt helt tilfældige rejse. Til sidst ender han i Zürich (hvor Kracht er født), og forestiller sig her, at han engang vil komme til at bo i bjergene, som ses i horisonten, med sin drømmepige Isabella Rosselini og deres børn: "Jeg ville så fortælle dem om Tyskland, om det store land i Nord, om den store maskine, der bygger sig selv op, dér nede i fladlandet" (p. I6o). Vel ude af Tyskland er han langt inde i den tyske myte, som bl.a. Nietzsche og Thomas Mann så ihærdigt har brugt: blikket fra oven på det meningstomme fladland, der som en maskine kværner sin egen død. Men som Manns Hans Castorp i Der Zauberberg må Krachts fortæller alligevel ned og ud i dette fladland - for at opsøge Manns grav i Kilchberg uden for Zürich. Det er dog blevet for mørkt til, at han kan finde den, til gengæld ender han til allersidst ved bredden af Zürichersøen, hvor han møder en mand med en robåd. Han beder ham om at blive sat over vandet, og et sted midt ude på søen slutter romanen. Züricher-søen har forvandlet sig til floden Styx, og den søgende fortæller, der ikke fandt mytedanneren Thomas Manns grav, bliver i en udvidet betydning af Charon sat over til dødens rige.

Her er det stedet at minde om, at også en anden af Thomas Manns helte, digteren Gustav von Aschenbach, i slutningen af Døden $i$ Venedig kommer ud at sejle med Charons færge i skikkelse af en gondol, og at døden i denne bog som andre steder i forfatterskabet ikke alene er associeret med vand, men også kommer fra øst. Denne kombination er nemlig tydelig i det største forfatterskab i sidste halvdel af det 20. århundrede, Günter Grass', hvis betydning for den nye tyske litteratur synes overvældende. Tragisk i hans sidste bog, Im Krebsgang, med flygtningeskibet fra øst, der går ned i Østersøen i januar I945, komisk gennemspillet i Unkenrufe fra 1993 med dens beretning om de østfordrevnes opkøb af kirkegårdsjord $\mathrm{i}$ de tidligere hjemlande. I Ein weites Feld fra 1995, hvor Tysklandsbilledet distribueres med en fantastisk variationsrigdom af landskabstyper fra øst til vest, tager de to hovedpersoner, Fonty og Hofthaler på dagen for Murens fald, 9. november 1989 , ud til de østtyske brunkulslejer i Lausitz. Her i det hærgede, sumpede moselandskab med de forladte eller stadigt fungerende kæmpehuller og grundvandssøer vil Hofthaler vise Fonty, hvorfor det ikke er nogen god idé med den genforening, som nu toner frem i horisonten. Den del af Tyskland, den østlige, som nu skal integreres er ikke andet end slagger og affald, og vil blive en møllesten om halsen på det nye Tyskland. Sådan siger den evige stikker og spion, Hofthaler, der her taler på vegne af sin forfatter, der i lang tid efter 1989 var modstander af det stortyske projekt. Tingene er dog som altid hos Grass komplicerede, i nærheden af det ødelagte månelandskab ligger der nemlig et nydeligt lille slot, Altdöbern, der lige som andre østtyske slotte er en arv fra dette dødens land egnet og parat at tage med ind $\mathrm{i}$ fremtiden. Måske ligger der en fremtid for pensionisten Fonty i at eftergøre Theodor Fontane i hans Wanderungen durch die Mark Brandenburg ${ }^{\mathrm{I2}}$ og blive en guide i det forenede tyske landskabs kulturhistorie. Østen er hos Grass ikke kun død og destruktion, men også fantasi og kreativitet. 
Det er grundlæggende den samme figur, vi finder i Karen Duves Regenroman fra I999, der allerede i sine mottoer (men ironisk-distanceret) annoncerer sig som en bog om syndfloden. "Det onde trives på fugtige steder", lyder et af dem, og det må man umiddelbart sige, at det gør på dette sted i Vorpommern-Mecklenburg, hvortil Hamburg-forfatteren og plattenslageren Leon Ulbricht er flyttet for at skrive en bestilt biografi over en alfons, han kender fra Hamburg-miljøet. Det kommer der en grotesk og sine steder helt Rabelaisk historie ud af, for derude i det østlige sumpland regner det hele tiden og det hus, som Ulbricht og hans kone Martina har købt, regner $\mathrm{i}$ bogstavelig forstand ned $\mathrm{i}$ dyndet. Ved siden af bor to ligeså groteske søstre, den ene enormt fed, den anden enormt høj. Den første, Isidora, forfører Leon i et orgie af kød og slim, den anden, Kay, reparerer huset, så godt det lader sig gøre. Midt i det hele opsøges Leon af alfonsen, der synes det går for langsomt med biografien, men da han bliver voldelig, dræber Kay ham og medhjælperen med en gasbrænder og sænker ligene ned i et vandhul. Det kriminelle Vesten har forsøgt at usurpere det amorfe, syndflodsagtige Østen, men det lader sig ikke integrere. Sumpen æder det hele.

Og det er på en måde det positive budskab i Regenroman. For kvinderne synes at kunne klare sig $\mathrm{i}$ dette regnorgie og ligefrem drage nytte af det. Som da Martina er på tur i landskabet med hunden Noah:

Birketræer, mos, flade langstrakte enge med kæruld, tørveagtige tuer, mat changerende vandhuller, mahognibrune dyr, som smuttede forbi deres fødder, og slør af vanddamp, som på afstand forekom så tyk som vælling, men som senere blev mere og mere gennemsigtigt og til sidst usynligt, jo nærmere man kom. Himlens og jordens forening... Letfodet sprang Martina over uudgrundelige sumphuller, følte sig lykkelig, usårlig og uovervindelig; følte sig som den bedste jæger i en matriarkalsk stenalderhorde. Mændene? De sad i hulen og trak tørrede svampe på snor, mens hun, ulvekvinden, skaffede kød og holdt udkig efter fjenden. ${ }^{13}$

Det er også denne evne til at springe over sumpen, der i den sidste ende bevirker, at Martina kan forlade Leon og tage tilbage til Hamborg for at foretage et opgør med sin fortid; mens Leon forsvinder i dyndet som "sank [han] tilbage i sin sande moders skød" (p. 227). Lige som de kaschubiske sumpe i Grass' Die Blechtrommel er de østlige vand-lande kvindeligt konnoterede: farlige og dødelige for de svage mænd, men også livgivende og befriende. Dobbeltheden udnyttes af Karen Duve, der sammen med bl.a. Judith Hermann, som vi vender tilbage til nedenfor, af den tyske kritik er blevet omtalt med den noget chauvinistiske betegnelse "das Fräuleinwunder". Men kraft er der i dem.

Det er der for så vidt også i Christoph Peters, der i 1999 debuterede med den bemærkelsesværdige roman Stadt Land Fluss. Også den handler om oversvømmelse og død,I4 her dog placeret $\mathrm{i}$ det vestlige Tyskland, i Niederrhein, lige før den store flod løber ind i Holland. Fra landsbyen Niel i denne egn stammer den lidt forhutlede kunsthistoriker Thomas Walkenbach, specialist i en lokal billedskærer Douwermann, men uden energi til at få en afhandling om ham gjort færdig. Som Douwermann i sine træskærerarbejder fortaber Thomas sig i detaljer og forsiringer, mister så at sige centralperspektivet uden hvilket man ikke kan bedrive videnskab. Til gengæld forelsker han sig i sin tandlæge, gifter sig med hende og lader sig halvvejs forsørge af hende, indtil hun får konstateret kræft og dør. Thomas' liv løber nu helt ud i opløsning.

Sådan som floden har tilbøjelighed til at gøre det i den egn, Thomas stammer fra. Heller ikke her i Niederrhein kan man etablere et centralperspektiv:

Måske kan man ikke forstå renæssancen, når man ser den fra Niel. Måske er centralperspektivet et urbant fænomen, koblet til stor bebyggelsestæthed med komplekse arkitektoniske former, udtænkt af mennesker, der helst opholder sig i lukkede rum og foretrækker lige gadeslugter, mørke floddale. ${ }^{\text {Is }}$

Perspektivet her er amorft og strukturerer ikke:

Til at give et landskab, ligegyldigt om det er fladt eller med bjerge, et præg af dybde skal der ikke mere til end tågebanker over et slynget vandløb, mellem bjergkamme, en gradvis udtynding af farver og kontraster hen mod horisonten, tilsætning af mere og mere blåt. I det fjerne en gård, et tempel, røg, der 
stiger op, halvt skjult af træer, så tæller forkortelsen af perspektivet ikke meget. Nogle traner på himlen. (p. 181)

Men det perspektiv er væk over Niel, her hersker den utydelighed og tilfældighed, der tiltrækker Thomas og som til slut i romanen fylder ham med en følelse af at være kommet hjem, selv om hans elskede Hanna er død:

Hjemme. Det var et landskab, meget fladt, næsten ingen skov, tyndt bebygget. Lerbankerne ved Rhinen, af leret kunne man forme fugle, der ikke ville flyde bort. Om sommeren regnede det ofte. Til gengæld faldt der sjældent sne om vinteren. Hverken det ene eller det andet var, som man gerne ville have, det skulle være. (p. 212)

Ganske vist er floden nu blevet reguleret med diger, men oversvømmelsesmetaforen slynger sig alligevel gennem bogen, både $\mathrm{i}$ dens frugtbare aspekter (festerne i Niel som vild livsglæde) og i dens uhyggelige perspektiver (kræftsvulsten der vokser uhæmmet). Dette flodlandskab opløser storbyens hierarkier og ordner, sletter erindring. Thomas' forskning om Douwermann afslører ganske vist mange ting, men viser først og fremmest de gåder $\mathrm{i}$ hans liv, han ikke kan løse. Hans tidligere studiekammerat Eva gør nu videnskabelig karriere ved at klamre sig til latterlige detaljer. Hun kan skabe perspektiv ved at indskrænke sit blik på verden. Thomas er en drømmer, der helst uafbrudt vil drikke af Lethe-strømmen, sådan som det var de gamles trøst i Niel (jfr. p. 56).

Når denne Lethe-association med fordel kan trækkes frem, er det fordi den antyder det dobbelte i det billede af flodlandskab i ny tysk litteratur, som her forsøges opridset. Floden og vandet er nok frugtbart og livgivende, men rummer også opløsning og død. ${ }^{6}$ Lethe er da også et nøglebegreb i en anden af de betydelige nye tyske romaner, hvor landskabet spiller en afgørende rolle. Det er HansUllrich Treichels roman Tristanakkord fra 2000, forfatterens anden efter den meget roste debut Der Verlorene. Dens hovedperson, Georg Zimmer, er også vokset op på bredden af en flod, Ems i øvrigt ikke langt fra den nedre Rhin. Og også for ham er barndommens flod forbundet med drøm og glemsel:
Når han sad ved flodbredden med køerne og det flade, nøgne land bag ved sig og det altid let grønligt skinnende vand foran sig, blev han ofte grebet af en barnlig-munter tomhed. Han så sit liv svømme ned ad det brede vandløb... ${ }^{17}$

Det er da baggrunden for, at han som uddannet germanist udkaster et ph.d.-projekt om 'glemslen i litteraturen' - "Lethe og ikke Mnemosyne", som hans vejleder formulerer det - et projekt han også får midler til at gennemføre.

Men om det nogensinde vil lykkes ham er tvivlsomt, for i mellemtiden bliver han sekretær for en berømt komponist, Bergmann, som arbejder på et værk, der også har med en flod at gøre. "Pyriphlegeton for stort orkester" hedder Bergmanns komposition, opkaldt efter den 'ildflod' som i antikkens mytiske univers omgav De elysiske marker og var én af Styx' bifloder. ${ }^{18}$ Forholdet mellem Georg og Bergmann bliver da et forhold mellem ild og glemsel, skønt Bergmann også stammer fra Emsland og i sin kosmopolitiske tilværelse hele tiden føler sig forbundet med Georg via deres fælles hjemstavn. Denne hjemstavn og dens landskab er da også hele vejen det sammenligningsgrundlag, Georg har med sig på sine rejser efter Bergmann rundt $\mathrm{i}$ verden: enten det er på Hebriderne, i USA (hvor han træffer et ægtepar, der forsøger at kultivere den mosplante, han kender så godt fra Emsland) eller Sicilien, hvor romanen opløser sig lige så uafgjort og tilfældigt, som den akkord i Wagners Tristan und Isolde, der har givet den dens titel. Til sidst giver Bergmann Georg den opgave at skrive en hymne til sit sidste værk, en hymne der i Hölderlins stil skal kombinere det lokale og det kosmopolitiske: “'En Hölderlin', sagde Bergmann, 'der nok vandrer rundt i Schwaben, men som samtidigt har et penthouse i New York"' (p. Ioo). Bergmann satser på, at Georg kan præstere en sådan syntese, men det er ved romanens slutning tvivlsomt, om det vil lykkes. Det er imidlertid denne syntese, der er romanens egen identitet, og den lykkes. Gennem Georgs bevidsthed ser vi alverdens steder og landskaber blendet med Emslands natur, selv i New York har han sit hjemland med sig, på godt og ondt. Under indtagelse af temmelig meget 
hvidvin har han en drøm i Central Park, om hvordan alverdens floder løber sammen:

Georg fugtede sin pande og sine tindinger med duggen, han drak vinen, han nød øjeblikket, han hørte ikke stemmen mere og kiggede på gondolen, som pludselig forekom ham at være Karons båd, som fragter sjælene over i underverdenen. Han sad ved Styx' bred, han sad ved Lethestrømmens bred, han sad ved Ems eller ved Tiberen, eller måske var det Canal Grande. (p. 85)

Treichel er typisk for ny tysk litteratur, ikke alene fordi han viser det regionales og det kosmopolitiskes forening, men også fordi han som uddannet germanist (der fungerer både som professor i Berlin og leder af Litteraturinstituttet i Leipzig) er så intenst optaget af landskabets kulturhistoriske koder. I den forstand er hans landskaber altid gennemstrømmet af erindring, og hans Ems altid også Styx, Lethe, Tiberen, Rhinen, Canal Grande og alle de andre. Med de litterære allusioner, der er knyttet hertil. Det kan gøre ham irriterende at læse for nogle, men giver også hans naturskildringer en tidsmæssig og kulturel dybde. "Poetische Landschaft".

Selv i de intense, minimalistiske former, der som i de fleste vestlige lande også spiller en fremtrædende rolle i ny tysk litteratur, er landskabet og det præcise sted en vigtig faktor. Judith Hermanns novellesamling Sommerhaus, später har siden sin udgivelse 1998 af den tyske kritik været anset for ét af højdepunkterne i denne litteratur, måske fordi Hermann kombinerer fornemmelse for ungdommens livsstil og sprog med en beherskelse af den klassiske novelleform. En grundakse i hendes små fortællinger er kontrasten mellem by og land, ofte mellem Berlin og den omgivende Mark Brandenburg, der også hos hende er kendetegnet af søer og floder. I titelnovellen "Sommerhus, senere" har den berlinske taxachauffør Stein en drøm om at få sig et hus langt derude, på den anden side af Angermünde, hvor han kan samle den klike, han knap nok er medlem af. Han får også skaffet sig en sum penge, men flugtdrømmen er (naturligvis) futil. Huset viser sig at være lige så forfaldent som det tilsvarende i Karen
Duves Regenroman, og han får aldrig mod til at invitere nogen ud til det. Kun fortælleren bliver på en besigtigelsestur indviet i den skrøbelige idyl og det sarte landskab, der omgiver den, men kort efter annoncerer en ulykke på en frossen sø, at idyllen er uholdbar. Det sidste livstegn fra Stein er et brev med et udklip fra Angermünde lokalavis indeholdende en notits om, at huset er brændt og dets ejer forsvundet. Stein er ligesom Leon i Regenroman symbolsk forsvundet ud i den brandenburgske sump. Også for hovedpersonen i den sidste af novellerne, "På denne side af Oder", er det sumpede flodlandskab stedet for en slags flugt fra en forpligtende storbyeksistens og for det selvopgør, han ikke har styrke til at foretage. Det er som om der dér østligt i Tyskland befinder sig en tyngende og bedøvende stemning, der fordrer dagdrømmeri og mental eller fysisk forsvinden. At denne del af Tyskland tidligere hed DDR giver problemstillingen en politisk dimension (jfr. navnet på Karen Duves antihelt Leon Ulbricht: 'le on', 'das Man' foran den gamle stalinist), men det ikke fordi det politiske spiller en fremtrædende rolle. Det er mere sådan, at de enkelte hjørner af Tyskland udstyres med sjælelige kvaliteter, at landskabet er psykisk farvet. Igen: et poetisk landskab.

Og selvfølgelig er døden i ny tysk litteratur ikke kun bundet til den østlige del - den findes også $\mathrm{i}$ vest og ikke kun i landskabet, men ligefuldt i de store byer. Matthias Altenburgs roman Landschaft mit Wölfen, endnu én af de store succeser fra de seneste år (udkommet 1997), udspiller sig i bylandskabet, metropolen Frankfurt, under syv dages hedebølge en juli måned. Men med den samme udnyttelse af de konkrete steder (gader, butikker, kirker, osv.) som meget af den øvrige nye tyske litteratur. dtv's udgave har udstyret forsiden med Frankfurts mondæne skyline - en af de mest amerikanske i Europa - men det er noget af en tilsnigelse: det er det snuskede, nedslidte, forvirrede og larmende bylandskab, Altenburg skildrer, befolket af mennesker, der alle, som én af personerne siger, er beboet af et sort dyr - ulven. Jeg-fortælleren Neuhaus (hvis navn er en slags spejlvending af forfatterens) bukker for enden af hedebølgen under for sit indre dyr og dræber syv personer i et meningsløst skyderi, hvorefter han bliver 
jaget og fanget af en anden bande vilde dyr: politiet. I storbyens jungle kæmper ulv mod ulv og det skildres kynisk og koldt, i en stil der bevidst kontrasterer med den varme, der hærger byen i disse syv dage. Det er stærkt og præcist gjort, men set før.

Hvad der imidlertid løfter Landschaft mitWölfen ud af den store mængde moderne storbyromaner er den raffinerede brug Altenburg her gør af det symbol, der er gennemgående i denne fremstilling: floden og døden i vandet. ${ }^{19}$ Gennem de fleste storbyer i verden løber en flod, der har været afgørende i de litterære skildringer af denne by, i Frankfurts tilfælde er det Main. Ned til Main søger Neuhaus, når han vil slippe fri af byens hektiske puls, og her møder han en dag en dreng, der bor sammen med sin mor i en campingvogn ved bredden. Sammen med ham oplever han et øjebliks inderlig fortrolighed, selv om drengen nok så makabert mest er optaget af at begrave døde frøer. Også andre steder antydes det, at flodbilleder for Neuhaus rummer en utopisk, befriende stemning, bl.a. når han drømmer sig væk sammen med en gammel, violinspillende kvinde, der bor ved siden af ham.

Derfor er det også chokerende, at drengen netop drukner i floden, en dag hvor der endelig er kommet lidt kølighed i luften, og landskabet derfor er dækket af tåge. Der går en direkte virkning fra denne episode til Neuhaus vilde skyderi til slut i romanen. Meningsløsheden i denne død understreges af, at en mystisk blind mand står og beder ved bredden, mens frømænd leder efter drengen. En kristent farvet understrøm løber i det hele taget gennem romanen, intoneret af mottoet fra salme I30: "Fra dybet råber jeg, Herre, til dig”. Der råbes i denne bog efter nåde, men der er intet der tyder på, at råbet bliver hørt. De små utopiske glimt af håb druknes i den samme flod, ved hvis bred de opstod. Det er et poetisk flodlandskab, når det er mest knugende.

Øst-vest-dikotomien har altid været fatal i tysk litteratur, hvad enten den nu distribueredes som ratio og storby i Vest og natur og undergang i Øst, eller med andre fordelinger af de sjælelige landskabsværdier. Nord har spillet en underordnet rolle i den tyske bevidsthed.20 En vigtig rolle har til gengæld Syden spillet: “dahin, dahin” har tyskeren længtes, til “das Land wo die Zitronen blühn”, og hvor de puritanske bånd ikke føltes så snærende. De romaner, der i denne sammenhæng er blevet berørt, har vist, at denne længsel stadig er levende; Georg Zimmers rejse hos Treichel ender på Sicilien, Thomas hos Peters flygter med sin tandlæge-kone til den italienske riviera, også Krachts jeg-fortæller rejser mod syd, men kommer kun til Alperne, hvor han til gengæld aktiverer en anden dyb tysk arketype: længslen mod bjergene.

Til slut i denne lille skitse skal imidlertid omtales en roman fra den nye tyske litteratur, hvor Nord-Syd aksen er helt central. Det drejer sig om Andreas Maiers roman Klausen fra 2002, hans anden efter debuten Wäldchestag 200I. Maier har som flere af sine yngre kolleger valgt for en tid at bo i Sydtirol, en provins der både er del af sydens Italien og del af det tyske sprogområde. Et behageligt kompromis, skulle det synes, og herom handler også Klausen, der er navnet på en landsby i Sarca-dalen (på tysk Eisack), der på italiensk hedder Chiusa. Ned igennem denne dal løber foruden floden Sarca i dag også motorvejen fra Brenner-passet, og det har selvfølgelig ændret hele dalens miljø, især har det støjramt Klausen og omgivelser. Kampen om denne motorvej er nu aksen i handlingen, der hovedsagelig består af direkte eller indirekte gengivelse af landsbybeboernes tanker $i$ et kompliceret spil mellem indføling og ironi. Det er i sig selv fint gjort.

Når jeg trækker Klausen frem i denne sammenhæng er det dog først og fremmest for at pege på den måde, Maier bruger et billede af den tyske maler og træskærer Albrecht Dürer på. Dürer opholdt sig også et par sæsoner i Klausen i begyndelsen af I500-tallet og malede bl.a. her sit billede "Nemesis", også kaldet "Das grosse Glück", der viser en stor, nøgen kvinde på en kugle (den straffende Nemesis med retfærdighedens sværd) - men nedenunder og i baggrunden et idyllisk landskab, der strækker sig fra floden op ad bjergskråninger: det er Klausen, drømmen om en sydlandsk utopi, der undslipper den moralske strenghed. Denne utopi er der i dag flere, der søger at videreføre i Klausen, bl.a. dem der kæmper mod støjforureningen; men også maleren Pareith, der har forsøgt sig med en retoucheret vi- 
dereførelse af Dürer, nu helt idyl uden antydet hybris og straffende gudinde. Kampen bølger frem og tilbage i Klausen og slutter uafgjort med en lidt forkølet aktion mod motorvejstrafikken.

Og i den forstand kan romanen ses som symptomatisk for ny tysk litteraturs forhold til landskabet: på den ene side viderefører den de store klassiske motiver og typologier, på den anden side kan den ikke undgå at registrere, at myterne kun er levende som ironiske pasticher eller kitchede efter-billeder. Unge tyske forfattere slipper ikke den konkrete forankring i landskabet og kender deres lands geografi i detaljer; men en inderlig forbundethed med landskabet er tabt, hvis den nogensinde har været der. Så kan man lave nok så mange poesiparker rundt omkring. Den der siger "Et in Arcadia Ego" er allerede udenfor, som Simon Schama - smerteligt - må konkludere. ${ }^{2 I}$ Alligevel er en læsning af ny tysk litteratur på mange måder en lystrejse i det tyske landskab med tilliggende egne. Eller en opdagelsesrejse, hvor forfatter og læser i fællesskab begiver sig ud for at finde det land, som vi ved ligger der - men ikke lige hvor. I teksterne finder vi det, "poetische Landschaft".

\section{Noter}

I. Peter Waterhouse, f. I956, østrigsk mor, engelsk far, har samlet tekster om og refleksioner over landskabet i Die Geheimlosigkeit. Ein Spazier- und Lesebuch, Salzburg 1996. En bog til at gå rundt og læse i landskabet.

2. IX. Druck des Literaturbüros Ostwestfalen-Lippe in Detmold e.V., Detmold 200r.

3. op. cit., p. 84 (min oversattelse).

4. op. cit., p. 85 (m.o.).

5. op. cit., p. 22 (m.o.).

6. Per Øhrgaard: Arv og gaeld. Tre essays om Tyskland, Kbh. I99I, p. 70.

7. Da Husets forlag i 1985 udsendte min oversættelse af Günter de Bruyns østtyske provinsroman Studier i Mark'en fik jeg forlaget til at lave en forside med et kortudsnit, der viste det område, hvor romanen foregår, med nogle af de navne der er nævnt $\mathrm{i}$ teksten. $\mathrm{Og}$ så henover den lokalitet, hvor jeg vidste Günter de Bruyn boede, at gentage områdets navn: Mark'en (Mark Brandenburg). En finte, jeg har på fornemmelsen, at kun de Bruyn selv opdagede! Da forlaget i 2000 udsendte en oversættelse af Dieter Wellershofs 1972 skrevne Jagten på en forbryder, gentog man imidlertid idéen med kortet som forside, nu af det område i udkanten af Köln, hvor handlingen udspiller sig. Uden fremhævning af forfatterens bosted, til gengæld er kortet til endnu større nytte ved læsningen, da romanens hovedperson udnytter sit detaljerede kendskab til landskabet $\mathrm{i}$ sin legen-kispus med politiet. Forsiden bliver da led i læserens identifikation med den jagede. Begavet lay-out.

8. Jfr. Gudrun Tempels bog fra 1962: Deutschland? Aber wo liegt es? Wiederbegegnung mit einem Vaterland.

9. W.G. Sebald: Austerlitz, München 200I, p. 322 (m.o.). Io. Som var titlen på Christa Wolfs roman fra 1974, der tematiserede den romantiske drøm om dette 'intetsted' - i tydelig kritisk opposition til hendes meget 'realexistierende' DDR.

II. Christian Kracht: Faserland, Köln I995, p. I7 (m.o.). I2. fra I862: et af de første eksempler i tysk litteratur på en slentrende landskabskulturhistorie.

I3. Karen Duve: Regnroman, oversat af Anneli Høier, Kbh. 2000 , p. I62.

I4. Dette skrives august 2002, mens det østlige Tyskland kæmper med den største flodkatastrofe i historisk tid. Det bliver spændende at følge, om denne begivenhed får konsekvenser for den flodmetafor i ny tysk litteratur, som denne artikel giver nogle nedslag i.

I5. Christoph Peters: Karlighed langs et flodlandskab, oversat af Claes Kastholm Hansen, Højbjerg 2000, p. I80.

I6. Glemselsmotivet er således stort set fraværende i Simon Schamas i øvrigt vidtspændende gennemgang af flodmyten i europæisk kultur i Landscape and Memory fra I995. Schamas ærinde er Arcadia, hvor alle livets floder løber sammen og al erindring opbevares. Denne myte eksisterer kun i ny tysk (og anden?) litteratur som parodi.

I7. Hans-Ullrich Treichel: Tristanakkord, oversat af Anneli Høier, Kbh. 200I, p. 12.

I8. Se f.eks. Vergils Eneiden 6. sang, vers 55I. I9. Jfr. T.S. Eliots The Waste Land, IV. sang "Death by Water". At den nye tyske litteratur så udpræget holder fast $\mathrm{i}$ grundlæggende natur- og landskabssymboler kan tolkes som en af dens måder at holde fast i den store, modernistiske tradition bag om al den dekonstruktive opgør med samme tradition.

20. En fin oversigt over den betydning Norden trods alt har haft i tysk kultur og over den forskning, der har registreret den, finder man i Klaus Bohnen: "Der 'Mythos vom Norden' in deutscher Kulturtradition" in: Text \& Kontext, Sonderreihe, Band 43, Kopenhagen/München 2000.

2I. Jfr. Simon Schama: Landscape and Memory, New York I995, p. 5I7ff. 